\title{
mRNA Translation and Energy Metabolism in Cancer: The Role of the MAPK and mTORC1 Pathways
}

\author{
I. Topisirovic ${ }^{1}$ And N. SonenBerG ${ }^{2}$ \\ ${ }^{1}$ Lady Davis Institute for Medical Research, Jewish General Hospital and Department of Oncology, \\ McGill University, Montreal H3T 1E2, Canada \\ ${ }^{2}$ Department of Biochemistry and Goodman Cancer Research Centre, McGill University, \\ Montreal H3A 1A3, Canada \\ Correspondence: nahum.sonenberg@mcgill.ca; ivan.topisirovic@mcgill.ca
}

\begin{abstract}
mRNA translation is the most energy-consuming process in the cell and strongly correlates with cellular metabolic activity. Translation and energy metabolism play important roles in homeostatic cell growth and proliferation, and when dysregulated lead to cancer. eIF4E is a key regulator of translation, which promotes oncogenesis by selectively enhancing translation of a subset of tumor-promoting mRNAs (e.g., cyclins and c-myc). PI3K/AKT and mitogen-activated protein kinase (MAPK) pathways, which are strongly implicated in cancer etiology, exert a number of their biological effects by modulating translation. The PI3K/AKT pathway regulates eIF4E function by inactivating the inhibitory 4E-BPs via mTORC1, whereas MAPKs activate MAP kinase signal-integrating kinases 1 and 2, which phosphorylate eIF4E. In addition, AMP-activated protein kinase, which is a central sensor of the cellular energy balance, impairs translation by inhibiting mTORC1. Thus, eIF4E plays a major role in mediating the effects of PI3K/AKT, MAPK, and cellular energetics on mRNA translation.
\end{abstract}

A prominent feature of cancer cells is the use of aerobic glycolysis under conditions in which oxygen levels are sufficient to support energy production in the mitochondria (Jones and Thompson 2009; Cairns et al. 2010). This phenomenon, named the "Warburg effect," after its discoverer Otto Warburg, is thought to fuel the biosynthetic requirements of the neoplastic growth (Warburg 1956; Koppenol et al. 2011) and has recently been acknowledged as one of the hallmarks of cancer (Hanahan and Weinberg 2011).

mRNA translation is the most energy-demanding process in the cell (Buttgereit and Brand 1995). In mammalian cells it consumes $\sim 20 \%$ of cellular ATP, not considering the energy that is required for the biosynthesis of the components of the translational machinery (e.g., ribosome biogenesis; Buttgereit and Brand 1995). Control of mRNA translation plays a pivotal role in the regulation of gene expression (Sonenberg and Hinnebusch 2009). In fact, a recent study demonstrated that mammalian proteome is mostly governed at the mRNA translation level (Schwanhausser et al. 2011).

Malfunction of mRNA translation critically contributes to human disease, including diabetes, heart disease, blood disorders, and, most notably, cancer (Fig. 1; Crozier et al. 2006; Narla and Ebert 2010; Silvera et al. 2010; Spriggs et al. 2010). The first account of changes in the translational apparatus in cancer dates back to 1896 , showing enlarged and irregularly shaped nucleoli that are the site of ribosome biogenesis (Pianese 1896). Rapidly proliferating cancer cells have more ribosomes than normal cells (Delaunay and Schapira 1974; Johnson et al. 1976; Montanaro et al. 2008; Silvera et al. 2010).
In stark contrast to normal cells, in cancer cells ribosomal biogenesis is uncoupled from cell proliferation (Stanners et al. 1979). Accordingly, cancer cells exhibit abnormally high rates of protein synthesis (Silvera et al. 2010). That ribosomal dysfunction plays a central role in cancer is further corroborated by the findings that genetic alterations, which encompass the components of the ribosome machinery (i.e., "ribosomopathies"), are characterized by elevated cancer risk (Narla and Ebert 2010).

\section{INITIATION, A KEY REGULATORY STEP OF TRANSLATION}

mRNA translation proceeds in three steps: initiation, elongation, and termination (Mathews et al. 2007). Each of the steps consists of a series of highly orchestrated interactions between the mRNA and several factors, including ribosomes, aminoacyl-transfer RNAs (tRNAs), and auxiliary proteins collectively referred to as the translational factors (Mathews et al. 2007). Although all steps of mRNA translation are highly regulated, most of the translational control occurs at the ratelimiting initiation step (Sonenberg and Hinnebusch 2009; Jackson et al. 2010).

The vast majority of eukaryotic mRNAs are translated in a cap-dependent manner (Sonenberg and Hinnebusch 2009; Jackson et al. 2010). The eIF4F complex binds to the cap structure, which is present at the $5^{\prime}$-end of all nuclear-encoded eukaryotic mRNAs (Topisirovic et al. 2011). This complex consists of the cap-binding protein eukaryotic translation initiation factor (eIF) 4E (eIF4E), 


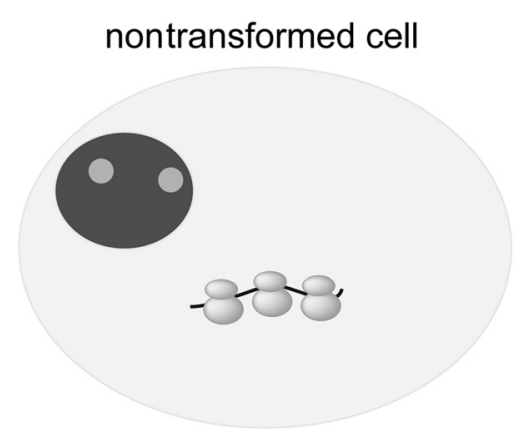

- Increase in the number of ribosmes

- Mutations in:

ribosomal proteins

(e.g., DBA)

enzymes involved in rRNA processing

(e.g., X-DC)

- Alterations in the levels and/or activity of

malignantly transformed cell translation factors (e.g., elfs) and tRNA $A_{i}^{M e t}$
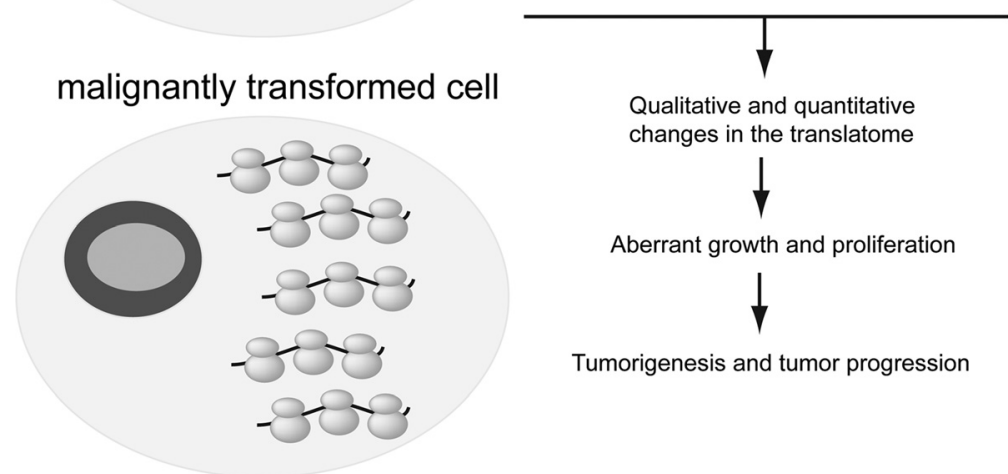

Figure 1. Dysregulated mRNA translation plays a pivotal role in cancer. Malignant cells are characterized by enlarged nucleoli and a larger number of ribosomes than their normal counterparts. Mutations and/or altered expression of ribosomal proteins (e.g., RPS19, RPS 24), rRNA-modifying enzymes (e.g., dyskerin), translation initiation factors (e.g., eIF4E), or the initiator tRNA (tRNA $\mathrm{A}_{i}^{\text {Met }}$ ) result in malignant transformation. Signaling pathways whose dysfunction is frequent in cancer (e.g., MAPK, PI3K/AKT) affect mRNA translation. Perturbations in the translatome result in aberrant cellular growth, proliferation, and survival characteristic of tumorigenesis.

the RNA helicase eIF4A and the scaffolding protein eIF4G (Gingras et al. 1999b; Sonenberg and Hinnebusch 2009; Jackson et al. 2010). The role of eIF4E in translation initiation, as well as the mode of its binding to the $5^{\prime}$ mRNA-cap structure, are conserved from yeast to human (Altmann et al. 1985; Marcotrigiano et al. 1997; Matsuo et al. 1997). eIF4G interacts directly with eIF4E, eIF3, the poly(A)-binding protein (PABP), and eIF4A (Sonenberg and Hinnebusch 2009; Jackson et al. 2010). eIF3 is a multicomponent factor that facilitates the recruitment of the $40 \mathrm{~S}$ ribosomal subunit (Sonenberg and Hinnebusch 2009; Jackson et al. 2010). eIF4A unwinds the secondary structure present in the $5^{\prime}$ untranslated region (UTR) of mRNA (Sonenberg and Hinnebusch 2009; Jackson et al. 2010), whereas the interaction of eIF4G and PABP leads to the circularization of the mRNA, which facilitates the recycling of the ribosomes on the mRNA, to stimulate translation (Kahvejian et al. 2005).

\section{EIF4E: A PROTO-ONCOGENIC PROTEIN THAT SELECTIVELY STIMULATES THE TRANSLATION OF MRNAS ENCODING TUMOR-PROMOTING FACTORS}

Alterations in the expression and/or function of a number of eIFs or tRNA $A_{i}^{\text {Met }}$ have been linked to tumorigenesis (Fig. 1; Marshall et al. 2008; Silvera et al. 2010). Amongs eIFs, the role of eIF4E in cancer is perhaps the best established (De Benedetti and Graff 2004; Graff et al. 2008). Its overexpression results in neoplastic transformation of rodent and human immortalized cells (Lazaris-Karatzas et al. 1990; Avdulov et al. 2004) and is tumorigenic in vivo (Ruggero et al. 2004; Wendel et al. 2007). Expression of eIF4E is elevated in a large number of malignancies including cancers of breast, colon, prostate, head, and neck, lymphomas, and leukemias (De Benedetti and Graff 2004; Graff et al. 2008).

eIF4E is the most limiting among eIFs (Sonenberg and Hinnebusch 2009). Thus, its availability critically determines translation initiation rates (Sonenberg and Hinnebusch 2009). Notwithstanding that eIF4E acts as a general translation initiation factor, its overexpression does not strongly promote global protein synthesis but rather selectively stimulates translation of a subset of mRNAs referred to as "eIF4E-sensitive" (Koromilas et al. 1992; Graff et al. 2008). In general, these mRNAs contain long, highly structured $5^{\prime}$ UTRs and are thus expected to be highly dependent on the unwinding activity of the eIF4A subunit of eIF4F for efficient translation (Sonenberg and Hinnebusch 2009; Parsyan et al. 2011). "eIF4E-sensitive" mRNAs encode proliferation and survival promoting factors and proto-oncogenic proteins, such as cyclins, c-myc, and $\mathrm{Bcl}_{\mathrm{xL}}$ (De Benedetti and Graff 2004; Graff et al. 2008). Translation of mRNAs bearing short, unstructured $5^{\prime}$ UTRs (e.g., tubulins, actins) is less dependent on the unwinding activity of eIF4A, and these mRNAs are only marginally sensitive to alterations in eIF4E levels (De Benedetti and Graff 2004; Graff et al. 
2008). Thus, the proto-oncogenic activity of eIF4E stems from its ability to selectively stimulate translation of mRNAs, which encode tumor-promoting factors.

\section{REGULATION OF EIF4E ACTIVITY AND CANCER}

Hyperactivation of eIF4E in cancer is a consequence of up-regulation of its expression and/or alterations in the signaling pathways that activate it (De Benedetti and Graff 2004; Graff et al. 2008; Sonenberg and Hinnebusch 2009; Silvera et al. 2010). Expression of eIF4E is controlled by a variety of mechanisms including transcriptional regulation by c-myc (Jones et al. 1996) and modulation of mRNA stability by HuR and AUF1 (Fig. 2; Topisirovic et al. 2009b). eIF4E is a major downstream effector of the mitogen-activated protein kinase (MAPK) and the phosphoinositide-3-kinase (PI3K)/AKT/mechanistic/mammalian target of rapamycin (mTOR) pathways, which are frequently dysregulated in cancer (Fig. 2; Dhillon et al. 2007; Guertin and Sabatini 2007; Cargnello and Roux 2011; Zoncu et al. 2011).

\section{MNKS AND EIF4E: DOWNSTREAM OF MAPKs}

In mammals, eIF4E is phosphorylated at Ser209 by the MAPK signal-integrating kinases 1 and 2 (MNK1 and MNK2; Fukunaga and Hunter 1997; Waskiewicz et al. 1997). Whereas MNK2 is constitutively active, MNK1 is activated by stimuli such as phorbol-esters and growth factors or by cytokines and stress via an extracellular signal-regulated kinase (Erk) and p38 mitogen activatedprotein kinase (MAPK), respectively (Wang et al. 1998; Scheper et al. 2001). Genetic studies in Drosophila revealed that the loss of eIF4E phosphorylation results in developmental defects and smaller flies (Lachance

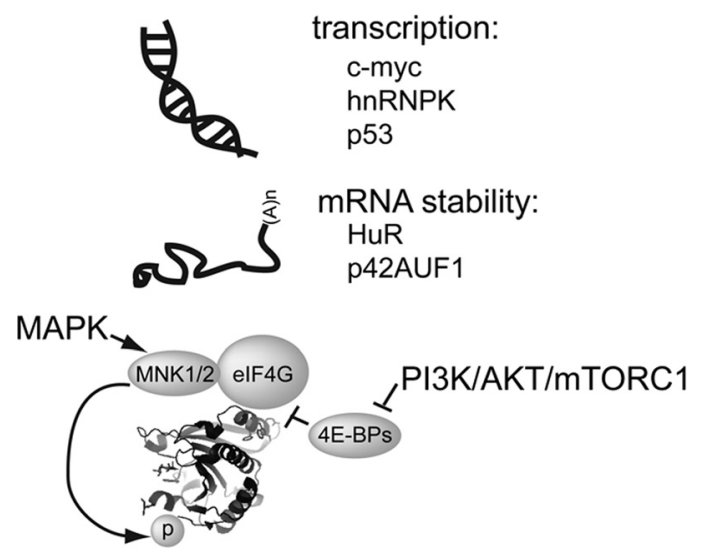

Figure 2. eIF4E is regulated by multiple mechanisms. The expression of eIF4E is regulated by several transcription factors (e.g., c-myc, hnRNPK, p53) and adenine-uracil-rich element binding proteins (i.e., HuR and AUF1). eIF4E is suppressed by $4 \mathrm{E}-\mathrm{BPs}$, which are regulated by mTORC1. MAP kinase signalintegrating kinases 1 and 2 (MNKs) phosphorylate eIF4E. et al. 2002). However, Mnkl/2 $2^{-/-}$mice develop normally and do not exhibit any gross phenotypic changes (Ueda et al. 2004).

eIF4G directly binds MNKs (Pyronnet et al. 1999). Therefore, the phosphorylation of eIF4E by MNKs takes place after the assembly of the eIF4F complex, and is thus positioned to have a major effect on translation initiation (Pyronnet et al. 1999). Nevertheless, how eIF4E phosphorylation influences cap-dependent translation is unclear. Depending on the experimental conditions, eIF4E phosphorylation has been reported to correlate with increased (Kaspar et al. 1990; Manzella et al. 1991; Walsh and Mohr 2004; Worch et al. 2004) or decreased global mRNA translation (Knauf et al. 2001; Morley and Naegele 2002; Naegele and Morley 2004). Phospho-eIF4E may also selectively stimulate translation of a subset of mRNAs, including Mcl-1 (Wendel et al. 2007).

Nonphosphorylatable mutant of eIF4E exhibits markedly impaired oncogenic potential as compared with wild-type eIF4E (Topisirovic et al. 2004; Wendel et al. 2007). To further establish the role of the phosphorylation of eIF4E in tumorigenesis, knockin mice expressing a nonphosphorylatable form of eIF4E were engineered (Furic et al. 2010). Similar to $M n k 1 / 2^{-/-}$animals, the eIF4E knockin mice do not exhibit any conspicuous phenotype (Furic et al. 2010). Nonetheless, embryonic fibroblasts isolated from these mice show lesser transformation capacity by oncogenes, such as Ras, in combination with c-myc (Furic et al. 2010). Crossing eIF4E knockin mice with animals in which the tumor suppressor phosphatase and tensin homolog (Pten) gene was selectively ablated in the prostate attenuated the early onset of high-grade prostate intraepithelial neoplasia and development of invasive carcinoma (Furic et al. 2010). Taken together, these results demonstrate that the phosphorylation of eIF4E is required for tumorigenesis caused by the loss of PTEN function. These observations are further corroborated by a study showing that the loss of MNK1/2 expression attenuates neoplastic growth in the loss-ofPTEN background (Ueda et al. 2010).

Phospho-eIF4E levels are highly elevated in human prostate cancers where they positively correlate with high Gleason scores, which are indicative of aggressive disease progression (Furic et al. 2010). A subset of mRNAs is differentially translated as a function of the phosphorylation status of eIF4E, including mRNAs encoding proteins important for tumor progression, such as inflammatory molecules $\mathrm{Ccl} 2$ and $\mathrm{Ccl} 7$ and the matrix metalloproteases, MMP3 and MMP9 (Furic et al. 2010). Thus, eIF4E phosphorylation appears to stimulate tumor inflammation and invasion by selectively affecting translation of mRNA that encodes proteins critical for these processes.

\section{DOWNSTREAM FROM mTORC1: 4E-BPs GOVERN THE ACTIVITY OF EIF4E}

The activity of eIF4E is also controlled by the 4Ebinding proteins (4E-BPs; Pause et al. 1994; Sonenberg 
and Hinnebusch 2009). In mammals, the 4E-BP family of proteins consists of 4E-BP1, 4E-BP2, and 4E-BP3 (Sonenberg and Hinnebusch 2009). 4E-BPs bind to the same site on eIF4E as eIF4G (Mader et al. 1995; Matsuo et al. 1997), thus preventing association of eIF4E with eIF4G and the eIF4F complex assembly. This reduces cap-dependent translation initiation (Pause et al. 1994).

mTOR phosphorylates 4E-BPs, causing their dissociation from eIF4E (Ma and Blenis 2009; Dowling et al. 2010b; Zoncu et al. 2011). mTOR is present in two distinct complexes: mTOR complex 1 (mTORC1) and mTOR complex 2 (mTORC2; Martin and Hall 2005; Dowling et al. 2010b; Zoncu et al. 2011). mTORC1 phosphorylates substrates such as 4E-BPs, ribosomal protein S6 kinases 1 and 2 (S6Ks), proline-rich Akt substrate of $40 \mathrm{kDa}$ (PRAS40) and serine/threonine kinase Ulk1 to regulate a variety of cellular processes including translation, proliferation, growth, metabolism and autophagy (Zoncu et al. 2011). mTORC2 phosphorylates members of the AGC kinase family (e.g., AKT, SGK1 and PKC) and controls cell survival and cytoskeletal organization (Sarbassov et al. 2004, 2005; Guertin and Sabatini 2007; Garcia-Martinez and Alessi 2008).

mTORC1 is activated by a multitude of extracellular stimuli and intracellular cues such as hormones, growth factors, and nutrients via various signaling pathways including the PI3K/AKT pathway and Ras-related small GTP-binding proteins (Rag-GTPases; Fig. 3; Sengupta et al. 2010; Zoncu et al. 2011). mTORC1 is a major regulator of translation (Ma and Blenis 2009). Activation of mTORC1 leads to initial phosphorylation of 4E-BPs on amino acids corresponding to Thr 37 and 46 in human 4E-BP1 (Brunn et al. 1997; Hara et al. 1997; Gingras et al. 1999a, 2001), which act as priming sites for the phosphorylation of residues corresponding to $\mathrm{Thr} 70$ and Ser 65, leading to its dissociation from eIF4E (Gingras et al. 1999a, 2001). Importantly, the loss of 4E-BP1 and 2, or the expression of a nonphosphorylatable mutant of $4 \mathrm{E}-\mathrm{BP} 1$, which constitutively binds to eIF4E, only marginally affects global translation levels (Lynch et al. 2004; Colina et al. 2008). This is consistent with the findings that eIF4E affects translation of only a subset of "eIF4E-sensitive" mRNAs (Graff and Zimmer 2003; De Benedetti and Graff 2004; Graff et al. 2008; Sonenberg and Hinnebusch 2009). Indeed, selected mRNAs (e.g., IRF-7, Gas2, cyclin D3, ODC, and VEGF) are translated more efficiently in the absence of 4E-BPs (Colina et al. 2008; Petroulakis et al. 2009; Dowling et al. 2010a).

In addition to 4E-BPs, mTORC1 modulates translation by activating S6K1 and 2 (Hay and Sonenberg 2004; Ma and Blenis 2009; Dowling et al. 2010b; Zoncu et al. 2011). Notwithstanding the expanding catalog of the targets of S6Ks, which are implicated in translational control such as ribosomal protein S6 (rpS6; Banerjee et al. 1990; Kozma et al. 1990), eukaryotic initiation factor 4B (eIF4B; Shahbazian et al. 2006), and programmed cell death 4 protein (PDCD4; Dorrello et al. 2006), it is not precisely known how S6Ks impact translation. Global translation is only marginally affected by the loss of S6K expression and modestly increased in mouse embryonic fibroblasts expressing the nonphosphorylatable mutant of rpS6 as compared to wild-type cells (Pende et al. 2004; Ruvinsky et al. 2005). It was suggested that S6Ks control translation of the $5^{\prime}$ terminal oligopyrimidine tract (5'TOP) containing mRNAs, which encode components of the translational machinery (Kawasome et al. 1998; Shima et al. 1998; Loreni et al. 2000). However, neither S6K expression nor the phosphorylation status of ribosomal protein S6 influences translation of 5'TOP mRNAs (Tang et al. 2001; Pende et al. 2004; Ruvinsky et al. 2005). Thus, the role of S6Ks in the regulation of mRNA translation is still moot.

mTORC1 was also suggested to promote translational initiation via the phosphorylation of eIF4G (Raught et al. 2000) and elongation by indirectly inhibiting the eukaryotic translation elongation factor 2 kinase (eEF2kinase; Redpath et al. 1996). It also stimulates rRNA and tRNA synthesis by activating TIF-IA and inhibiting the repressor of RNA polymerase III transcription MAF1 homolog, respectively (Mayer et al. 2004; Kantidakis et al. 2010; Shor et al. 2010).

\section{mTORC1, 4E-BPs, AND REGULATION OF CELL GROWTH AND PROLIFERATION}

The control of cell proliferation (increase in cell number) and growth (increase in cell volume) is intimately linked inasmuch as cell cycle progression is tightly coordinated with the increase in cell size (Hartwell et al. 1974; Nurse et al. 1976; Zetterberg et al. 1995; Jorgensen and Tyers 2004). In yeast, the $G_{1}$ cell cycle checkpoint START restricts the cell from entering the $S$ phase if the availability of growth factors and nutrients is insufficient (Hartwell et al. 1974; Nurse et al. 1976). The START checkpoint prevents cells proceeding through the cell cycle if they do not reach a certain size (Hartwell et al. 1974; Nurse et al. 1976). Thus, in yeast, cell size acts as a sensor for nutrient availability to ensure that cells enter the mitotic cycle only when nutrient availability is optimal (Hartwell et al. 1974; Nurse et al. 1976). In higher eukaryotes, cells must overcome similar, but multiple, growth-factor- and nutrient-dependent cell size restriction points to progress from the $G_{1}$ phase into the $\mathrm{S}$ phase of the cell cycle (Zetterberg et al. 1995). Importantly, progression through the $\mathrm{G}_{1}$ restriction point requires increased protein synthesis, as even moderate inhibition of mRNA translation causes exit from the $G_{1}$ phase of the cell cycle into a state of quiescence $\left(\mathrm{G}_{0}\right.$; Zetterberg et al. 1995).

The TOR pathway plays an evolutionarily conserved role in coordinating cell growth and cell proliferation (Wullschleger et al. 2006). In yeast, TOR1 promotes cell growth and thus impinges on cell cycle progression through the START checkpoint (Heitman et al. 1991; Martin and Hall 2005; De Virgilio and Loewith 2006). In Drosophila, dTOR regulates cell growth and proliferation by modulating the activity of dS6K and d4EBPs, whereby each protein regulates both growth and 


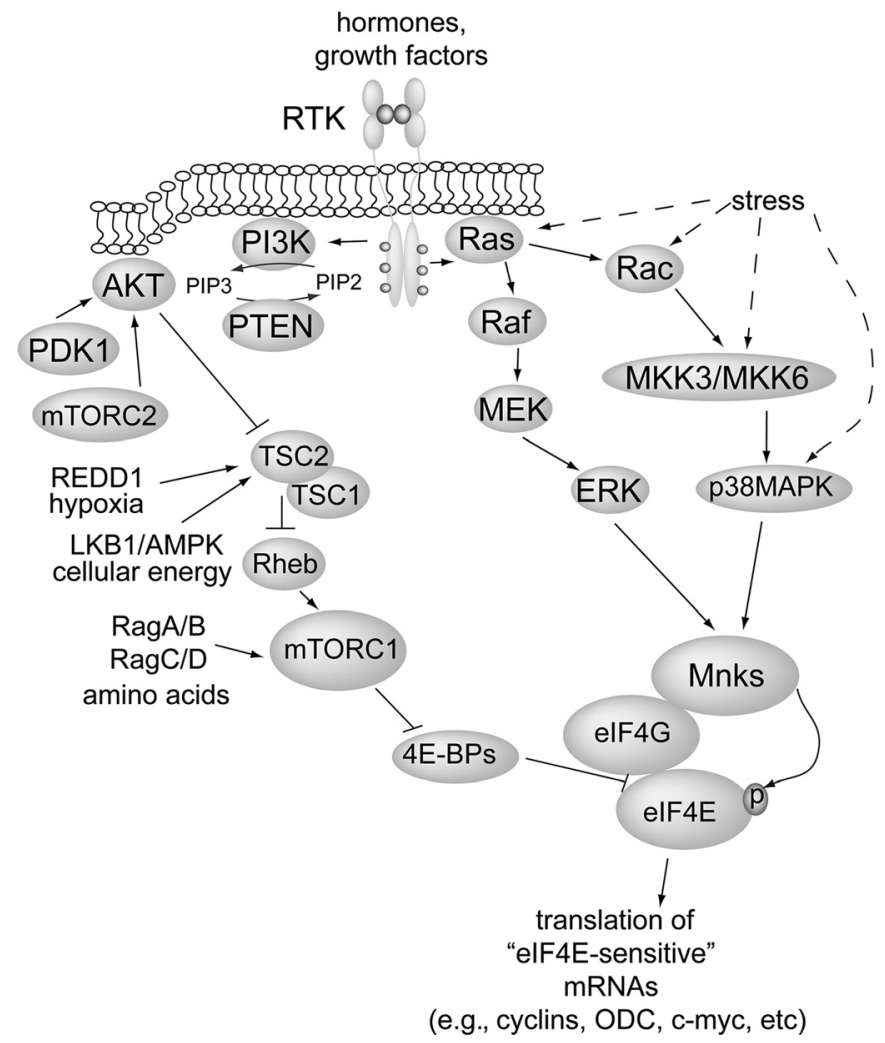

Figure 3. Ras/MAPK and PI3K/AKT/mTORC1 regulate the activity of eIF4E. Various stimuli activate phosphoinositide-3-kinase (PI3K) through the receptor tyrosine kinases (RTKs). Upon activation, PI3K converts phosphatidylinositol 4,5-bisphosphate (PIP2) into phosphatidylinositol-3,4,5-triphosphate (PIP3). This reaction is reversed by PTEN. Phosphoinositide-dependent protein kinase 1 (PDK1) and AKT bind to PIP3 via their pleckstrin homology domains, which allows for the phosphorylation and activation of AKT by PDK1. In addition, the mammalian target of rapamycin complex 2 (mTORC2) modulates the activity of AKT by phosphorylating its hydrophobic motif. AKT phosphorylates tuberous sclerosis complex 2 (TSC2) at multiple sites, which results in its inhibition and consequent activation of Ras homolog enriched in brain (Rheb), which is a small GTPase that activates mTORC1. mTORC1 phosphorylates 4E-BPs leading to their dissociation from eIF4E. In addition to the PI3K/AKT pathway, the activity of mTORC1 is regulated by the serine/threonine kinase 11/LKB1/AMP-kinase (LKB1/AMPK) pathway, regulated in development and DNA damage response 1 (REDD1) and Rag GTPases in response to the changes in cellular energy balance, oxygen and amino acid availability, respectively. Ras and the MAPK pathways are activated by various stimuli through receptor tyrosine kinases (RTKs). In addition the MAPK pathway is activated through the G protein-coupled receptors (GPCRs) and by protein kinase C (PKC; not shown). The MAPK pathways encompass an initial GTPase-regulated kinase (MAPKKK), which activates an effector kinase (MAPK) via an intermediate kinase (MAPKK). In response to stimuli such as growth factors, hormones, and phorbol-esters, Ras GTPase stimulates Raf kinase (MAPKKK), which activates extracellular signal-regulated kinases 1 and 2 (ERK 1 and 2) via extracellular signal-regulated kinase activator kinases MEK1 and 2 (MAPKK). Cellular stresses, including osmotic shock, inflammatory cytokines, and UV light, activate p38 MAPKs via multiple mechanisms including Rac kinase (MAPKKK) and MKK3 and 6 (MAPKK). p38 MAPK and ERK activate the MAPK signal-integrating kinases 1 and 2 (MNK1/2), which phosphorylate eIF4E. Additional abbreviations are provided in the text.

proliferation (Montagne et al. 1999; Miron et al. 2001). In contrast to insects, the loss of 4E-BP expression in mammalian cells has little impact on the reduction in cell size caused by mTOR inhibition (Dowling et al. 2010a). Conversely, mouse embryonic fibroblasts that do not express 4E-BPs proliferate faster than wild-type cells under conditions in which mTOR signaling is inhibited (Dowling et al. 2010a). Thus, the loss of 4E-BPs appears to alleviate the mTORC1-dependent cell size restriction point in $\mathrm{G}_{1}$ phase, inasmuch as mouse embryonic fibroblasts lacking 4E-BPs can efficiently enter the $\mathrm{S}$ phase of the cell cycle even under conditions when the cell growth is attenuated owing to the inhibition of mTORC1 signaling (Dowling et al. 2010a). In stark contrast to wild-type cells, suppression of mTORC1 in cells lacking 4E-BPs does not lead to translational down-regulation of cellcycle-promoting factors (e.g., cyclin D3 and ODC; Dowling et al. 2010a). Thus, 4E-BPs execute the effects of mTORC1 on cell proliferation by selectively regulating translation of mRNAs that are necessary for cell cycle progression (Fig. 4).

Factors that control the cell-size dependent $\mathrm{G}_{1}$ restriction point and accelerate entry into the $S$ phase of cell cycle, such as c-myc and D-type cyclins, are encoded by eIF4E-sensitive mRNAs (De Benedetti et al. 1994; Rosenwald et al. 1995; Rousseau et al. 1996; Graff and Zimmer 2003; Dowling et al. 2010a). Overexpression of c-myc results in the uncoupling of cell division from 

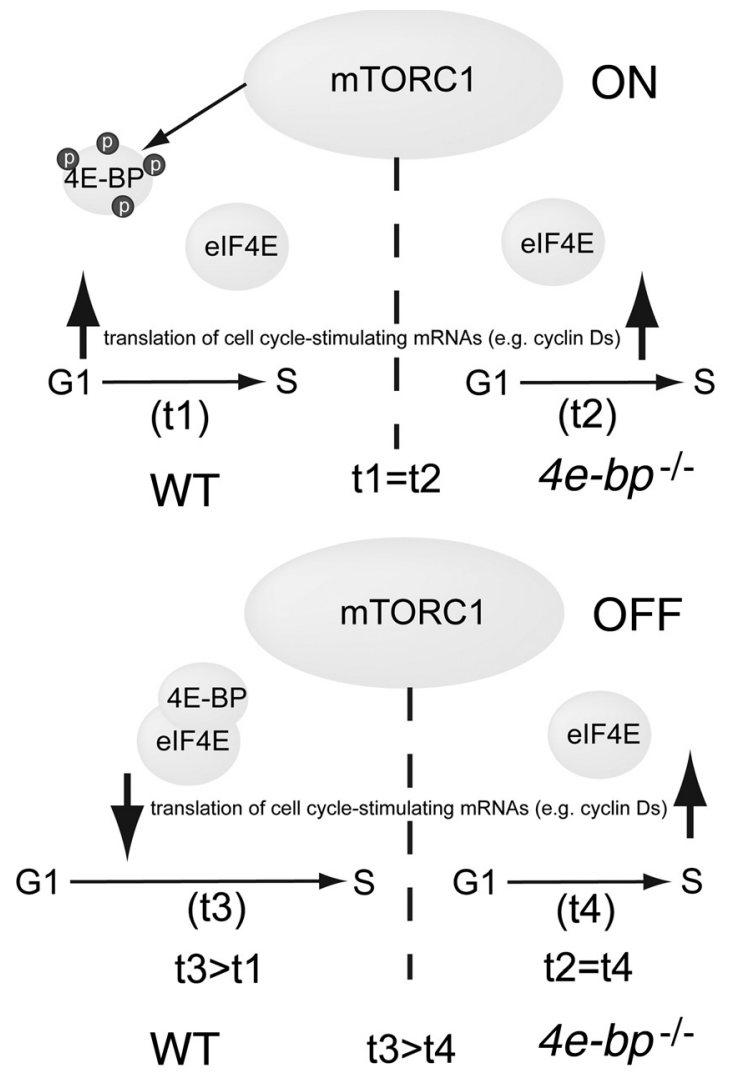

Figure 4. In mammals, 4E-BPs regulate cell cycle progression and proliferation, but not cell growth downstream of mTORC1. (Upper panels) Under optimal nutrient conditions, mTORC1 phosphorylates and inactivates 4E-BPs, which leads to the increase in translation of "eIF4E-sensitive" mRNAs encoding proteins required for the $\mathrm{S}$ phase entry and cell cycle progression. Under these conditions cells lacking 4E-BPs $\left(4 e-b p^{-/-}\right.$; $t 1$ ) and wild-type cells (WT; $t 2$ ) progress from the $\mathrm{G}_{1}$ to $\mathrm{S}$ phase of the cell cycle at the same rate $(t 1=t 2$ ). (Lower panels) Inhibition of mTORC1 signaling decreases the phosphorylation of 4E-BPs and translational activity of "eIF4E-sensitive" mRNAs. This results in the prolonged $\mathrm{G}_{1}$ phase ( $\left.t 3\right)$. Although the effect of mTORC1 inhibition on the reduction of cell size in $4 e-b p^{-1-}$ and wild-type cells is comparable, under these conditions $4 e-b p^{-1-}$ cells maintain efficient translation of eIF4E-sensitive mRNAs which enables them to enter into the $\mathrm{S}$ phase of the cell cycle $(t 4)$.

cell size, which is a consequence of the accelerated entry into the $\mathrm{S}$ phase of cell cycle (Kuystermans and Al-Rubeai 2009). Similarly, loss of N-myc expression in the mouse developing eye decreases proliferation, but not retinal cell size (Martins et al. 2008). Forced expression of D-type cyclins accelerates progression through the $G_{1}$ phase in mouse and rat fibroblasts and renders their proliferation resistant to serum deprivation (Quelle et al. 1993). Collectively, these data suggest that the uncoupling of cell size and cell proliferation is a consequence of dysregulated translation of "eIF4E-sensitive" mRNAs (Fig. 4).

Whereas S6Ks may play a role in regulation of cell proliferation in hepatocytes (Espeillac et al. 2011), in other cell types, including myoblasts and fibroblasts, S6Ks mediate the effects of mTORC1 on cell size, but not proliferation (Pende et al. 2004; Ohanna et al. 2005; Dowling et al. 2010a). The observed "division of labor" between 4E-BPs and S6Ks suggests that cell size and cell cycle control in most mammalian cell types can be uncoupled downstream of mTORC1, which is in sharp contrast to insects, in which 4E-BPs and S6Ks impact both cell proliferation and growth equally. Consistently, it has been reported that cell proliferation is largely independent of cell growth in mammalian Schwann cells, but not yeast (Conlon et al. 2001; Conlon and Raff 2003). In addition, proliferation and cell cycle progression in human lymphoblasts are independently modulated by cell size and age (i.e., time after division), whereby the probability of division for cells of the same size increases with age (Tzur et al. 2009). These results strongly suggest that mammals coordinate cell growth with cell proliferation via mechanisms that are distinct from those of evolutionarily lower organisms.

\section{mTORC1, 4E-BPs, ABERRANT CELL PROLIFERATION, AND TUMORIGENESIS}

Aberrant proliferation is a hallmark of cancer (Hanahan and Weinberg 2000; Hanahan and Weinberg 2011). Thus, it is not surprising that mTOR signaling is frequently deregulated in malignancies (Mamane et al. 2006; Guertin and Sabatini 2007). This can typically result from the inactivation of tumor suppressors such as LKB1 and PTEN, which antagonize PI3K-dependent activation of mTOR, or activating mutations in PI3K subunits (Inoki et al. 2003; Shaw et al. 2004a; Feng et al. 2005; Sabatini 2006). 4E-BPs are major downstream effectors of mTORC1 on cell proliferation (Dowling et al. 2010a). Studies using mTOR inhibitors provide evidence that 4E-BPs act as crucial mediators of oncogenic mTORC1 signaling. Rapamycin, a naturally occurring macrolide antibiotic and its analogs (rapalogs) function as allosteric inhibitors of mTORC1, but they do not inhibit mTORC2 in most cell types (Guertin and Sabatini 2009). Whereas rapalogs are used for the treatment of malignancies, such as advanced renal cell carcinoma, their overall success as cancer monotherapies has so far been disappointing (Guertin and Sabatini 2009). This has been attributed in part to the compensatory up-regulation of PI3K/AKT signaling owing to the inhibition of the activity of S6Ks by rapamycin (Manning 2004; Easton et al. 2006). ATP-competitive mTOR inhibitors [asTORi; e.g., PP242 (Feldman et al. 2009), Torin 1 (Thoreen et al. 2009) and Ku-0063794 (GarciaMartinez et al. 2009)], which target its catalytic site, were recently developed to overcome this problem. Unlike rapamycin, asTORi inhibit AKT signaling via down-regulation of mTORC2 signaling. These compounds also exhibit stronger antiproliferative effects than rapamycin (Feldman et al. 2009; Thoreen et al. 2009). Unexpectedly, the effects of asTORi on proliferation do not appear to be a consequence of the inhibition of AKT signaling, as they are $\mathrm{mTORC} 2$ independent 
(Feldman et al. 2009; Thoreen et al. 2009). Instead, asTORi decrease the phosphorylation of 4E-BPs much more potently than rapamycin, whereas their effects on S6Ks and their substrates are comparable (Feldman et al. 2009; Garcia-Martinez et al. 2009; Thoreen et al. 2009; Dowling et al. 2010a). These findings suggest that the superb antiproliferative effects of asTORi are caused by inhibition of rapamycin-resistant mTORC1 outputs toward 4E-BPs (Feldman et al. 2009; Thoreen et al. 2009). Accordingly, cells lacking 4E-BPs are resistant to the antiproliferative and antineoplastic effects of asTORi (Dowling et al. 2010a).

4E-BPs are down-regulated and/or hyperphosphorylated (i.e., inactivated due to the constitutively activated mTORC1 signaling) in breast, ovarian, and several other cancers (Castellvi et al. 2006; Petricoin et al. 2007; Rojo et al. 2007). Ectopic expression of a nonphosphorylatable, constitutively active mutant of 4E-BP1 suppresses the tumorigenicity of human breast carcinoma cells and c-myc-transformed rodent fibroblasts (Avdulov et al. 2004; Lynch et al. 2004). Recent data further corroborate the tenet that 4E-BPs act as tumor suppressors. Loss of 4E-BP expression in fibroblasts leads to premature senescence (Petroulakis et al. 2009), which mirrors the phenotype observed in cells lacking tumor suppressors such as PTEN (Chen et al. 2005). Similarly to cells lacking functional PTEN, the underlying mechanism of premature senescence in the $4 e-b p^{-/-}$background appears to be p53 dependent (Chen et al. 2005; Petroulakis et al. 2009). p53 protein levels are elevated in $4 e-b p 1 / 2^{-/-}$ cells, which is a consequence of increased translation of growth-arrest-specific 2 (Gas2) mRNA and subsequent increase in Gas 2 protein (Petroulakis et al. 2009). Gas 2 suppresses the degradation of p53 protein by inhibiting calpain protease activity (Benetti et al. 2001). In turn, the loss of 4E-BPs accelerates tumorigenesis in $p 53^{-/-}$ mice (Petroulakis et al. 2009). These results are further corroborated by the findings in which an AKT-driven lymphoma mouse model was deployed. In these experiments, expression of a constitutively active, nonphosphorylatable mutant of 4E-BP1 in AktT transgenic mice led to a dramatic decrease in lymphoma development (Hsieh et al. 2010). Notably, expression of a nonphosphorylatable mutant of rpS6, which is a major downstream target of S6Ks, in AktT transgenic animals failed to attenuate lymphomagenesis (Hsieh et al. 2010). These results suggest that, by suppressing eIF4E function, 4E-BPs act as major inhibitors of oncogenic Akt signaling (Hsieh et al. 2010). Indeed, the ability of a constitutively active, nonphosphorylatable 4E-BP1 mutant to suppress lymphomagenesis downstream of AKT appears to be a result of the inhibition of translation of "eIF4Esensitive" Mcl-1 mRNA (Hsieh et al. 2010). These findings are compatible with previous studies, revealing that oncogenic AKT signaling induces perturbations in mRNA translation and that elevated activity of eIF4E plays a major role in AKT-driven tumorigenesis (Rajasekhar et al. 2003; Wendel et al. 2004). Collectively, these studies strongly suggest that 4E-BPs act as bona fide tumor suppressors.

\section{EIF4E IS A CENTRAL NODE THAT LINKS MAPK AND PI3K/AKT SIGNALING}

The MAPK and PI3K/AKT pathways stimulate the activity of eIF4E via its phosphorylation and inactivation of 4E-BPs, respectively (Fig. 3). The phosphorylation of eIF4E requires the association of MNKs with eIF4G bound to eIF4E (Pyronnet et al. 1999). Down-regulation of PI3K/AKT signaling leads to increased binding of 4E-BPs to eIF4E and its dissociation from eIF4G (Pause et al. 1994). This raises the possibility that the PI3K/ AKT pathway may modulate MAPK-dependent phosphorylation of eIF4E indirectly by impairing the recruitment of MNKs to eIF4E via eIF4G. Surprisingly, it has been shown that rapamycin induces phosphorylation of eIF4E (Wang et al. 2007). This apparent discrepancy can be explained by the inability of rapamycin to completely and sustainably inhibit the phosphorylation of 4E-BPs (Choo et al. 2008), which is further exacerbated by the stimulatory effect of rapamycin on MAPK signaling (Carracedo et al. 2008). Consistently, asTORi diminish the phosphorylation of 4E-BPs and dramatically reduce the levels of phosphorylated eIF4E (Furic et al. 2010).

In cancer cells in which both MAPK and PI3K/AKT pathways are activated, inhibitors of each pathway alone fail as antiproliferative and proapoptotic agents, whereas a combination thereof strongly suppresses proliferation and induces apoptosis (Shaw and Cantley 2006). Oncogenic MAPK and AKT signals converge on 4E-BP1 (She et al. 2010). Accordingly, combined inhibition of MAPK and PI3K/AKT completely and sustainably inhibits the phosphorylation of 4E-BPs, which is paralleled by tumor growth reduction (She et al. 2010). These data indicate that the MAPK and PI3K/AKT pathways converge on eIF4E via multiple mechanisms and raise the intriguing possibility that both pathways exert their oncogenic effects at least in part by modulating translation of "eIF4E-sensitive" mRNAs.

\section{ENERGY METABOLISM AND mRNA TRANSLATION IN CANCER}

Increased cell growth and proliferation correlate with the elevated mRNA translation (Johnson et al. 1976). Thus, rapidly growing and proliferating cells need to accommodate the high-energy demand of mRNA translation (Buttgereit and Brand 1995). The AMP-activated protein kinase (AMPK) acts as an evolutionarily conserved sensor of the energy status of the cell (Kahn et al. 2005; Shaw 2009). AMPK is activated via upstream kinases such as serine/threonine kinase 11 (STK11/LKB1; Hawley et al. 2003; Woods et al. 2003; Lizcano et al. 2004; Shaw et al. 2004b; Suter et al. 2006) when nutrient or oxygen resources are limited, leading to increase in cellular AMP levels (Kahn et al. 2005; Shaw 2009). AMPK inhibits anabolic processes and impairs cell growth and proliferation (Kahn et al. 2005; Shaw 2009). In this way, AMPK acts as a central node to coordinate intracellular energy status with growth and proliferation (Kahn et al. 2005; 
Shaw 2009). This is in part achieved via mTORC1, which is one of the major downstream targets of the LKB1/ AMPK pathway (Shaw et al. 2004a). Importantly, downregulation of mTORC1 signaling is required for efficient cell cycle arrest and inhibition of proliferation following AMPK activation (Gwinn et al. 2008), which is paralleled by a decrease in mRNA translation (Dowling et al. 2007). Thus, the AMPK/mTOR pathway links energy metabolism with translational control and cell growth and proliferation.

In cancer cells, AMPK activity is frequently compromised, resulting in aberrant growth and proliferation (Wang and Guan 2009). This is in most circumstances a consequence of inactivating mutations in the $L K B 1$ gene (Wang and Guan 2009). The $L K B 1$ gene is mutated in Peutz-Jeghers syndrome (PJS) patients (Hemminki et al. 1998). This disorder is characterized by benign polyps in the gastrointestinal tract and increased predisposition to development of malignant tumors in a variety of tissues (Hearle et al. 2006). PJS, Cowden disease, and tuberous sclerosis patients share a large number of clinical features. Cowden disease and tuberous sclerosis are characterized by the hyperactivation of mTORC1 owing to the mutations in PTEN or tuberous sclerosis complex 1/2, respectively (Short et al. 1995; Liaw et al. 1997; Stambolic et al. 1998). Somatic LKB1 mutations are frequently detected in non-small-cell lung cancer patients (Sanchez-Cespedes et al. 2002; Ji et al. 2007). mTORC1 signaling is hyperacitvated in lung cancer cell lines in which the function of LKB1 is abrogated (Carretero et al. 2007). These data suggest that hyperactivation of mTORC1 contributes to LKB1-dependent tumorigenesis.

\section{CONCLUDING REMARKS}

The large body of data summarized here demonstrates that dysregulation of mRNA translational plays a paramount role in tumorigenesis and tumor progression. However, several important issues remain to be addressed. For instance, it is important to discern whether the mutations in ribosomal proteins characteristic of ribosomopathies affect their ribosomal or "extraribosomal" functions (i.e., cellular activities of ribosomal proteins that are not associated with their role in the ribosome; Wool 1996; Warner and McIntosh 2009). In response to DNA damage, ribosomal protein L26 (RPL26) promotes translation of p53 mRNA by directly binding to its $5^{\prime}$ UTR (Takagi et al. 2005). As RPL26 associates with the p53 mRNA in the nucleus, its role in regulating the expression of p53 is illustrative of its extraribosomal function (Chen and Kastan 2010). In addition to ribosomal proteins, eukaryotic translation factors have been suggested to have a role outside of mRNA translation. For instance, eIF4E appears to regulate the nucleocytoplasmic export of a subset of mRNAs (e.g., cyclin D1), which harbor a specific 4E-sensitivity element in their $3^{\prime}$ UTR (Rousseau et al. 1996; Culjkovic et al. 2005; Topisirovic et al. 2009a).

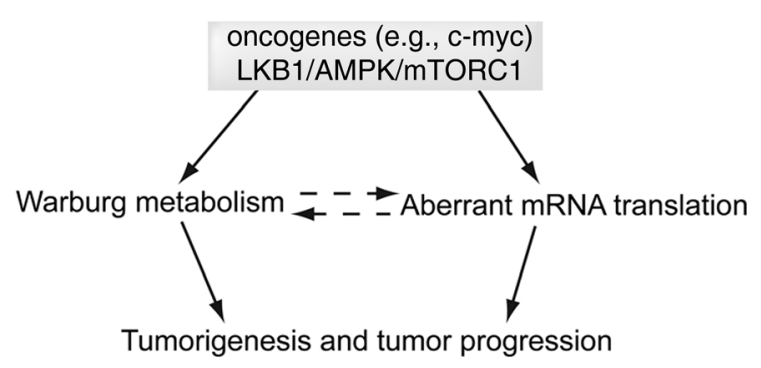

Figure 5. Potential link between malignant translatomes and metabolomes. Activation of oncogenes (e.g., c-myc) and/or aberrant activity of the signaling pathways (e.g., mTORC1, AMPK) lead to alterations in mRNA translation and metabolic activity in the cell. Given that mRNA translation is the most energy-consuming process in the cell, it is plausible that the translatome of malignant cells is affected by perturbations in energy metabolism, inasmuch as the malignant cells need to accommodate the elevated activity of the translational apparatus to the alterations in the energy balance. In turn, changes in translational activity of mRNAs encoding proteins implicated in the regulation of cellular metabolism may critically contribute to the Warburg effect observed in cancer cells. Future research is necessary to establish whether changes in cell metabolism influence mRNA translation and, vice versa, whether aberrant mRNA translation impacts the metabolome of malignant cells.

It is thought that cancers are frequently "addicted" to a high-energy supply (Cairns et al. 2010) and elevated protein synthesis (Silvera et al. 2010). Nonetheless, it is still not clear whether changes in cellular energetics in cancer cells affect mRNA translation and, vice versa, whether the perturbations in mRNA translation in cancer contribute to the changes in gene expression necessary for the Warburg effect (Fig. 5). A better understanding of the link between the dysregulation of mRNA translation and energy metabolism in cancer is necessary to devise better and more personalized therapeutic regiments in the future. Consistent with this hypothesis, metformin, a biguanide antidiabetic drug that has been shown to be associated with decreased incidence of cancer in diabetic patients (Larsson et al. 2005, 2007), affects energy metabolism and mRNA translation by modulating the activity of AMPK and mTORC1 via multiple mechanisms (Zakikhani et al. 2006; Dowling et al. 2007; Kalender et al. 2010; Ben Sahra et al. 2011).

Pianese (1896) observed irregularly shaped and enlarged nucleoli in malignant cells. Following this finding, a bevy of studies established a role for aberrant mRNA translation in neoplastic transformation and tumor progression. Thus, dysregulated mRNA translation represents a longstanding "hallmark of cancer" that remains to be recognized.

\section{ACKNOWLEDGMENTS}

We would like to thank Jean-Claude Labbé for critical reading of the manuscript. This work was supported by grants from the Canadian Cancer Society (N.S.), Canadian Institutes for Health Research (I.T.), and Terry Fox New Frontiers Program in Cancer (N.S. and I.T.). N.S. 
is an International Research Scholar of the Howard Hughes Medical Institute.

\section{REFERENCES}

Altmann M, Edery I, Sonenberg N, Trachsel H. 1985. Purification and characterization of protein synthesis initiation factor eIF-4E from the yeast Saccharomyces cerevisiae. Biochemistry 24: 6085-6089.

Avdulov S, Li S, Michalek V, Burrichter D, Peterson M, Perlman DM, Manivel JC, Sonenberg N, Yee D, Bitterman PB, Polunovsky VA. 2004. Activation of translation complex eIF4F is essential for the genesis and maintenance of the malignant phenotype in human mammary epithelial cells. Cancer Cell 5: $553-563$.

Banerjee P, Ahmad MF, Grove JR, Kozlosky C, Price DJ, Avruch J. 1990. Molecular structure of a major insulin/mitogen-activated 70-kDa S6 protein kinase. Proc Natl Acad Sci 87: $8550-8554$

Benetti R, Del Sal G, Monte M, Paroni G, Brancolini C, Schneider C. 2001. The death substrate Gas2 binds m-calpain and increases susceptibility to p53-dependent apoptosis. EMBO J 20: 2702-2714.

Ben Sahra I, Regazzetti C, Robert G, Laurent K, Le MarchandBrustel Y, Auberger P, Tanti JF, Giorgetti-Peraldi S, Bost F. 2011. Metformin, independent of AMPK, induces mTOR inhibition and cell-cycle arrest through REDD1. Cancer Res 71: 4366-4372.

Brunn GJ, Hudson CC, Sekulic A, Williams JM, Hosoi H, Houghton PJ, Lawrence JC Jr, Abraham RT. 1997. Phosphorylation of the translational repressor PHAS-I by the mammalian target of rapamycin. Science 277: 99-101.

Buttgereit F, Brand MD. 1995. A hierarchy of ATP-consuming processes in mammalian cells. Biochem $J$ 312(Pt 1): $163-$ 167.

Cairns RA, Harris IS, Mak TW. 2010. Regulation of cancer cell metabolism. Nat Rev Cancer 11: 85-95.

Cargnello M, Roux PP. 2011. Activation and function of the MAPKs and their substrates, the MAPK-activated protein kinases. Microbiol Mol Biol Rev 75: 50-83.

Carracedo A, Ma L, Teruya-Feldstein J, Rojo F, Salmena L, Alimonti A, Egia A, Sasaki AT, Thomas G, Kozma SC, et al. 2008. Inhibition of mTORC1 leads to MAPK pathway activation through a PI3K-dependent feedback loop in human cancer. J Clin Invest 118: 3065-3074.

Carretero J, Medina PP, Blanco R, Smit L, Tang M, Roncador G, Maestre L, Conde E, Lopez-Rios F, Clevers HC, SanchezCespedes M. 2007. Dysfunctional AMPK activity, signalling through mTOR and survival in response to energetic stress in LKB1-deficient lung cancer. Oncogene 26: 1616-1625.

Castellvi J, Garcia A, Rojo F, Ruiz-Marcellan C, Gil A, Baselga J, Ramon y Cajal S. 2006. Phosphorylated 4E binding protein 1: A hallmark of cell signaling that correlates with survival in ovarian cancer. Cancer 107: 1801-1811.

Chen J, Kastan MB. 2010. 5'-3'-UTR interactions regulate p53 mRNA translation and provide a target for modulating p53 induction after DNA damage. Genes Dev 24: 21462156.

Chen Z, Trotman LC, Shaffer D, Lin HK, Dotan ZA, Niki M, Koutcher JA, Scher HI, Ludwig T, Gerald W, et al. 2005. Crucial role of p53-dependent cellular senescence in suppression of Pten-deficient tumorigenesis. Nature 436: $725-$ 730.

Choo AY, Yoon SO, Kim SG, Roux PP, Blenis J. 2008. Rapamycin differentially inhibits S6Ks and 4E-BP1 to mediate cell-type-specific repression of mRNA translation. Proc Natl Acad Sci 105: 17414-17419.

Colina R, Costa-Mattioli M, Dowling RJ, Jaramillo M, Tai LH, Breitbach CJ, Martineau Y, Larsson O, Rong L, Svitkin YV, et al. 2008. Translational control of the innate immune response through IRF-7. Nature 452: 323-328.
Conlon I, Raff M. 2003. Differences in the way a mammalian cell and yeast cells coordinate cell growth and cell-cycle progression. J Biol 2: 7.

Conlon IJ, Dunn GA, Mudge AW, Raff MC. 2001. Extracellular control of cell size. Nat Cell Biol 3: 918-921.

Crozier SJ, Zhang X, Wang J, Cheung J, Kimball SR, Jefferson LS. 2006. Activation of signaling pathways and regulatory mechanisms of mRNA translation following myocardial ischemia-reperfusion. J Appl Physiol 101: 576-582.

Culjkovic B, Topisirovic I, Skrabanek L, Ruiz-Gutierrez M, Borden KL. 2005. eIF4E promotes nuclear export of cyclin D1 mRNAs via an element in the $3^{\prime}$ UTR. J Cell Biol 169: 245-256.

De Benedetti A, Graff JR. 2004. eIF-4E expression and its role in malignancies and metastases. Oncogene 23: 3189-3199.

De Benedetti A, Joshi B, Graff JR, Zimmer SG. 1994. CHO cells transformed by the translation factor eIF-4E display increased c-myc expression, but require overexpression of Max for tumorigenicity. Mol Cell Differ 2: 347-371.

Delaunay J, Schapira G. 1974. Ribosomes and cancer. Biomedicine 20: 327-332.

De Virgilio C, Loewith R. 2006. Cell growth control: Little eukaryotes make big contributions. Oncogene 25: 6392-6415.

Dhillon AS, Hagan S, Rath O, Kolch W. 2007. MAP kinase signalling pathways in cancer. Oncogene 26: 3279-3290.

Dorrello NV, Peschiaroli A, Guardavaccaro D, Colburn NH, Sherman NE, Pagano M. 2006. S6K1- and BTRCP-mediated degradation of PDCD4 promotes protein translation and cell growth. Science 314: 467-471.

Dowling RJ, Zakikhani M, Fantus IG, Pollak M, Sonenberg N. 2007. Metformin inhibits mammalian target of rapamycindependent translation initiation in breast cancer cells. Cancer Res 67: 10804-10812.

Dowling RJ, Topisirovic I, Alain T, Bidinosti M, Fonseca BD, Petroulakis E, Wang X, Larsson O, Selvaraj A, Liu Y, et al. 2010a. mTORC1-mediated cell proliferation, but not cell growth, controlled by the 4E-BPs. Science 328: 1172-1176.

Dowling RJ, Topisirovic I, Fonseca BD, Sonenberg N. 2010 b. Dissecting the role of mTOR: Lessons from mTOR inhibitors. Biochim Biophys Acta 1804: 433-439.

Easton JB, Kurmasheva RT, Houghton PJ. 2006. IRS-1: Auditing the effectiveness of mTOR inhibitors. Cancer Cell 9: $153-155$.

Espeillac C, Mitchell C, Celton-Morizur S, Chauvin C, Koka V, Gillet C, Albrecht JH, Desdouets C, Pende M. 2011. S6 kinase 1 is required for rapamycin-sensitive liver proliferation after mouse hepatectomy. J Clin Invest $\mathbf{1 2 1 .}$

Feldman ME, Apsel B, Uotila A, Loewith R, Knight ZA, Ruggero D, Shokat KM. 2009. Active-site inhibitors of mTOR target rapamycin-resistant outputs of mTORC1 and mTORC2. PLoS Biol 7: e38.

Feng Z, Zhang H, Levine AJ, Jin S. 2005. The coordinate regulation of the p53 and mTOR pathways in cells. Proc Natl Acad Sci 102: 8204-8209.

Fukunaga R, Hunter T. 1997. MNK1, a new MAP kinase-activated protein kinase, isolated by a novel expression screening method for identifying protein kinase substrates. EMBOJ 16: $1921-1933$.

Furic L, Rong L, Larsson O, Koumakpayi IH, Yoshida K, Brueschke A, Petroulakis E, Robichaud N, Pollak M, Gaboury LA, et al. 2010. eIF4E phosphorylation promotes tumorigenesis and is associated with prostate cancer progression. Proc Natl Acad Sci 107: 14134-14139.

Garcia-Martinez JM, Alessi DR. 2008. mTOR complex 2 (mTORC2) controls hydrophobic motif phosphorylation and activation of serum- and glucocorticoid-induced protein kinase 1 (SGK1). Biochem J 416: 375-385.

Garcia-Martinez JM, Moran J, Clarke RG, Gray A, Cosulich SC, Chresta CM, Alessi DR. 2009. Ku-0063794 is a specific inhibitor of the mammalian target of rapamycin (mTOR). Biochem J 421: 29-42.

Gingras AC, Gygi SP, Raught B, Polakiewicz RD, Abraham RT, Hoekstra MF, Aebersold R, Sonenberg N. 1999a. Regulation 
of 4E-BP1 phosphorylation: A novel two-step mechanism. Genes Dev 13: $1422-1437$.

Gingras AC, Raught B, Sonenberg N. 1999b. eIF4 initiation factors: Effectors of mRNA recruitment to ribosomes and regulators of translation. Annu Rev Biochem 68: 913-963.

Gingras AC, Raught B, Gygi SP, Niedzwiecka A, Miron M, Burley SK, Polakiewicz RD, Wyslouch-Cieszynska A, Aebersold R, Sonenberg N. 2001. Hierarchical phosphorylation of the translation inhibitor 4E-BP1. Genes Dev 15: 2852-2864.

Graff JR, Zimmer SG. 2003. Translational control and metastatic progression: Enhanced activity of the mRNA cap-binding protein eIF-4E selectively enhances translation of metastasisrelated mRNAs. Clin Exp Metastasis 20: 265-273.

Graff JR, Konicek BW, Carter JH, Marcusson EG. 2008. Targeting the eukaryotic translation initiation factor $4 \mathrm{E}$ for cancer therapy. Cancer Res 68: 631-634.

Guertin DA, Sabatini DM. 2007. Defining the role of mTOR in cancer. Cancer Cell 12: 9-22.

Guertin DA, Sabatini DM. 2009. The pharmacology of mTOR inhibition. Sci Signal 2: e24.

Gwinn DM, Shackelford DB, Egan DF, Mihaylova MM, Mery A, Vasquez DS, Turk BE, Shaw RJ. 2008. AMPK phosphorylation of raptor mediates a metabolic checkpoint. Mol Cell 30: $214-226$.

Hanahan D, Weinberg RA. 2000. The hallmarks of cancer. Cell 100: $57-70$.

Hanahan D, Weinberg RA. 2011. Hallmarks of cancer: The next generation. Cell 144: 646-674.

Hara K, Yonezawa K, Kozlowski MT, Sugimoto T, Andrabi K, Weng QP, Kasuga M, Nishimoto I, Avruch J. 1997. Regulation of eIF-4E BP1 phosphorylation by mTOR. J Biol Chem 272: $26457-26463$.

Hartwell LH, Culotti J, Pringle JR, Reid BJ. 1974. Genetic control of the cell division cycle in yeast. Science 183: 46-51.

Hawley SA, Boudeau J, Reid JL, Mustard KJ, Udd L, Makela TP, Alessi DR, Hardie DG. 2003. Complexes between the LKB1 tumor suppressor, STRAD $\alpha / \beta$ and MO25 $\alpha / \beta$ are upstream kinases in the AMP-activated protein kinase cascade. J Biol 2: 28.

Hay N, Sonenberg N. 2004. Upstream and downstream of mTOR. Genes Dev 18: 1926-1945.

Hearle N, Schumacher V, Menko FH, Olschwang S, Boardman LA, Gille JJ, Keller JJ, Westerman AM, Scott RJ, Lim W, et al. 2006. Frequency and spectrum of cancers in the Peutz-Jeghers syndrome. Clin Cancer Res 12: 3209-3215.

Heitman J, Movva NR, Hall MN. 1991. Targets for cell cycle arrest by the immunosuppressant rapamycin in yeast. Science 253: 905-909.

Hemminki A, Markie D, Tomlinson I, Avizienyte E, Roth S, Loukola A, Bignell G, Warren W, Aminoff M, Hoglund P, et al. 1998. A serine/threonine kinase gene defective in Peutz-Jeghers syndrome. Nature 391: 184-187.

Hsieh AC, Costa M, Zollo O, Davis C, Feldman ME, Testa JR, Meyuhas O, Shokat KM, Ruggero D. 2010. Genetic dissection of the oncogenic mTOR pathway reveals druggable addiction to translational control via 4EBP-eIF4E. Cancer Cell 17: 249-261.

Inoki K, Zhu T, Guan KL. 2003. TSC2 mediates cellular energy response to control cell growth and survival. Cell 115: $577-$ 590.

Jackson RJ, Hellen CU, Pestova TV. 2010. The mechanism of eukaryotic translation initiation and principles of its regulation. Nat Rev Mol Cell Biol 11: 113-127.

Ji H, Ramsey MR, Hayes DN, Fan C, McNamara K, Kozlowski P, Torrice C, Wu MC, Shimamura T, Perera SA, et al. 2007. LKB1 modulates lung cancer differentiation and metastasis. Nature 448: 807-810.

Johnson LF, Levis R, Abelson HT, Green H, Penman S. 1976. Changes in RNA in relation to growth of the fibroblast. IV. Alterations in the production and processing of mRNA and rRNA in resting and growing cells. J Cell Biol 71: 933-938.
Jones RG, Thompson CB. 2009. Tumor suppressors and cell metabolism: A recipe for cancer growth. Genes Dev 23: 537-548.

Jones RM, Branda J, Johnston KA, Polymenis M, Gadd M, Rustgi A, Callanan L, Schmidt EV. 1996. An essential E box in the promoter of the gene encoding the mRNA capbinding protein (eukaryotic initiation factor 4E) is a target for activation by c-myc. Mol Cell Biol 16: 4754-4764.

Jorgensen P, Tyers M. 2004. How cells coordinate growth and division. Curr Biol 14: R1014-R1027.

Kahn BB, Alquier T, Carling D, Hardie DG. 2005. AMPactivated protein kinase: Ancient energy gauge provides clues to modern understanding of metabolism. Cell Metab 1: $15-25$.

Kahvejian A, Svitkin YV, Sukarieh R, M'Boutchou MN, Sonenberg N. 2005. Mammalian poly(A)-binding protein is a eukaryotic translation initiation factor, which acts via multiple mechanisms. Genes Dev 19: 104-113.

Kalender A, Selvaraj A, Kim SY, Gulati P, Brule S, Viollet B, Kemp BE, Bardeesy N, Dennis P, Schlager JJ, et al. 2010. Metformin, independent of AMPK, inhibits mTORC1 in a rag GTPase-dependent manner. Cell Metab 11: 390-401.

Kantidakis T, Ramsbottom BA, Birch JL, Dowding SN, White RJ. 2010. mTOR associates with TFIIIC, is found at tRNA and 5S rRNA genes, and targets their repressor Maf1. Proc Natl Acad Sci 107: 11823-11828.

Kaspar RL, Rychlik W, White MW, Rhoads RE, Morris DR. 1990. Simultaneous cytoplasmic redistribution of ribosomal protein L32 mRNA and phosphorylation of eukaryotic initiation factor 4E after mitogenic stimulation of Swiss $3 \mathrm{~T} 3$ cells. J Biol Chem 265: 3619-3622.

Kawasome H, Papst P, Webb S, Keller GM, Johnson GL, Gelfand EW, Terada N. 1998. Targeted disruption of p70(s6k) defines its role in protein synthesis and rapamycin sensitivity. Proc Natl Acad Sci 95: 5033-5038.

Knauf U, Tschopp C, Gram H. 2001. Negative regulation of protein translation by mitogen-activated protein kinase-interacting kinases 1 and 2. Mol Cell Biol 21: 5500-5511.

Koppenol WH, Bounds PL, Dang CV. 2011. Otto Warburg's contributions to current concepts of cancer metabolism. Nat Rev Cancer 11: 325-337.

Koromilas AE, Lazaris-Karatzas A, Sonenberg N. 1992. mRNAs containing extensive secondary structure in their $5^{\prime}$ non-coding region translate efficiently in cells overexpressing initiation factor eIF-4E. EMBO J 11: 4153-4158.

Kozma SC, Ferrari S, Bassand P, Siegmann M, Totty N, Thomas G. 1990. Cloning of the mitogen-activated S6 kinase from rat liver reveals an enzyme of the second messenger subfamily. Proc Natl Acad Sci 87: 7365-7369.

Kuystermans D, Al-Rubeai M. 2009. cMyc increases cell number through uncoupling of cell division from cell size in $\mathrm{CHO}$ cells. BMC Biotechnol 9: 76 .

Lachance PE, Miron M, Raught B, Sonenberg N, Lasko P. 2002. Phosphorylation of eukaryotic translation initiation factor $4 \mathrm{E}$ is critical for growth. Mol Cell Biol 22: 1656-1663.

Larsson SC, Orsini N, Wolk A. 2005. Diabetes mellitus and risk of colorectal cancer: A meta-analysis. J Natl Cancer Inst 97: $1679-1687$

Larsson SC, Mantzoros CS, Wolk A. 2007. Diabetes mellitus and risk of breast cancer: A meta-analysis. Int $J$ Cancer 121: $856-862$.

Lazaris-Karatzas A, Montine KS, Sonenberg N. 1990. Malignant transformation by a eukaryotic initiation factor subunit that binds to mRNA $5^{\prime}$ cap. Nature 345: 544-547.

Liaw D, Marsh DJ, Li J, Dahia PL, Wang SI, Zheng Z, Bose S, Call KM, Tsou HC, Peacocke M, et al. 1997. Germline mutations of the PTEN gene in Cowden disease, an inherited breast and thyroid cancer syndrome. Nat Genet 16: 64-67.

Lizcano JM, Goransson O, Toth R, Deak M, Morrice NA, Boudeau J, Hawley SA, Udd L, Makela TP, Hardie DG, Alessi DR. 2004. LKB1 is a master kinase that activates 13 kinases of the AMPK subfamily, including MARK/PAR-1. EMBO J 23: $833-843$. 
Loreni F, Thomas G, Amaldi F. 2000. Transcription inhibitors stimulate translation of $5^{\prime}$ TOP mRNAs through activation of S6 kinase and the mTOR/FRAP signalling pathway. Eur $J$ Biochem 267: 6594-6601.

Lynch M, Fitzgerald C, Johnston KA, Wang S, Schmidt EV. 2004. Activated eIF4E-binding protein slows $\mathrm{G}_{1}$ progression and blocks transformation by c-myc without inhibiting cell growth. J Biol Chem 279: 3327-3339.

Ma XM, Blenis J. 2009. Molecular mechanisms of mTORmediated translational control. Nat Rev Mol Cell Biol 10: 307-318.

Mader S, Lee H, Pause A, Sonenberg N. 1995. The translation initiation factor eIF-4E binds to a common motif shared by the translation factor eIF-4 $\gamma$ and the translational repressors 4E-binding proteins. Mol Cell Biol 15: 4990-4997.

Mamane Y, Petroulakis E, LeBacquer O, Sonenberg N. 2006. mTOR, translation initiation and cancer. Oncogene 25: 6416-6422

Manning BD. 2004. Balancing Akt with S6K: Implications for both metabolic diseases and tumorigenesis. J Cell Biol 167: 399-403.

Manzella JM, Rychlik W, Rhoads RE, Hershey JW, Blackshear PJ. 1991. Insulin induction of ornithine decarboxylase. Importance of mRNA secondary structure and phosphorylation of eucaryotic initiation factors eIF-4B and eIF-4E. $J$ Biol Chem 266: 2383-2389.

Marcotrigiano J, Gingras AC, Sonenberg N, Burley SK. 1997. Cocrystal structure of the messenger RNA $5^{\prime}$ cap-binding protein (eIF4E) bound to 7-methyl-GDP. Cell 89: 951-961.

Marshall L, Kenneth NS, White RJ. 2008. Elevated tRNA(iMet) synthesis can drive cell proliferation and oncogenic transformation. Cell 133: 78-89.

Martin DE, Hall MN. 2005. The expanding TOR signaling network. Curr Opin Cell Biol 17: 158-166.

Martins RA, Zindy F, Donovan S, Zhang J, Pounds S, Wey A, Knoepfler PS, Eisenman RN, Roussel MF, Dyer MA. 2008. $\mathrm{N}$-myc coordinates retinal growth with eye size during mouse development. Genes Dev 22: 179-193.

Mathews MB, Sonenberg N, Hershey JWB. 2007. Translational control in biology and medicine (ed. Sonenberg N, Mathews MB, Hershey JWB). Cold Spring Harbor Laboratory Press, Cold Spring Harbor, NY

Matsuo H, Li H, McGuire AM, Fletcher CM, Gingras AC, Sonenberg N, Wagner G. 1997. Structure of translation factor eIF4E bound to m7GDP and interaction with 4E-binding protein. Nat Struct Biol 4: 717-724.

Mayer C, Zhao J, Yuan X, Grummt I. 2004. mTOR-dependent activation of the transcription factor TIF-IA links rRNA synthesis to nutrient availability. Genes Dev 18: 423-434.

Miron M, Verdu J, Lachance PE, Birnbaum MJ, Lasko PF, Sonenberg N. 2001. The translational inhibitor 4E-BP is an effector of $\mathrm{PI}(3) \mathrm{K} /$ Akt signalling and cell growth in Drosophila. Nat Cell Biol 3: 596-601.

Montagne J, Stewart MJ, Stocker H, Hafen E, Kozma SC, Thomas G. 1999. Drosophila S6 kinase: A regulator of cell size Science 285: 2126-2129.

Montanaro L, Trere D, Derenzini M. 2008. Nucleolus, ribosomes, and cancer. Am J Pathol 173: 301-310.

Morley SJ, Naegele S. 2002. Phosphorylation of eukaryotic initiation factor (eIF) 4E is not required for de novo protein synthesis following recovery from hypertonic stress in human kidney cells. J Biol Chem 277: 32855-32859.

Naegele S, Morley SJ. 2004. Molecular cross-talk between MEK1/2 and mTOR signaling during recovery of 293 cells from hypertonic stress. J Biol Chem 279: 46023-46034.

Narla A, Ebert BL. 2010. Ribosomopathies: Human disorders of ribosome dysfunction. Blood 115: 3196-3205.

Nurse P, Thuriaux P, Nasmyth K. 1976. Genetic control of the cell division cycle in the fission yeast Schizosaccharomyces pombe. Mol Gen Genet 146: 167-178.

Ohanna M, Sobering AK, Lapointe T, Lorenzo L, Praud C, Petroulakis E, Sonenberg N, Kelly PA, Sotiropoulos A, Pende M. 2005. Atrophy of S6K $1^{-/-}$skeletal muscle cells reveals distinct mTOR effectors for cell cycle and size control. Nat Cell Biol 7: 286-294.

Parsyan A, Svitkin Y, Shahbazian D, Gkogkas C, Lasko P, Merrick WC, Sonenberg N. 2011. mRNA helicases: The tacticians of translational control. Nat Rev Mol Cell Biol 12: $235-245$.

Pause A, Belsham GJ, Gingras AC, Donze O, Lin TA, Lawrence JC Jr, Sonenberg N. 1994. Insulin-dependent stimulation of protein synthesis by phosphorylation of a regulator of $5^{\prime}$-cap function. Nature 371: 762-767.

Pende M, Um SH, Mieulet V, Sticker M, Goss VL, Mestan J, Mueller M, Fumagalli S, Kozma SC, Thomas G. 2004. SK $61^{-/-}$and SK62 ${ }^{-1-}$ mice exhibit perinatal lethality and rapamycin-sensitive 5 -terminal oligopyrimidine mRNA translation and reveal a mitogen-activated protein kinase-dependent S6 kinase pathway. Mol Cell Biol 24: 3112-3124.

Petricoin EF III, Espina V, Araujo RP, Midura B, Yeung C, Wan X, Eichler GS, Johann DJ Jr, Qualman S, Tsokos M, et al. 2007. Phosphoprotein pathway mapping: Akt/mammalian target of rapamycin activation is negatively associated with childhood rhabdomyosarcoma survival. Cancer Res 67: 3431-3440.

Petroulakis E, Parsyan A, Dowling RJ, LeBacquer O, Martineau Y, Bidinosti M, Larsson O, Alain T, Rong L, Mamane Y, et al. 2009. p53-Dependent translational control of senescence and transformation via 4E-BPs. Cancer Cell 16: 439-446.

Pianese G. 1896. Beitrag zur histologie und Aetiologie der carcinoma histologische und experimentelle. Beitr Pathol Anat Allgem Pathol 142: 1-193.

Pyronnet S, Imataka H, Gingras AC, Fukunaga R, Hunter T, Sonenberg N. 1999. Human eukaryotic translation initiation factor $4 \mathrm{G}$ (eIF4G) recruits mnk1 to phosphorylate eIF4E. EMBO J 18: 270-279.

Quelle DE, Ashmun RA, Shurtleff SA, Kato JY, Bar-Sagi D, Roussel MF, Sherr CJ. 1993. Overexpression of mouse D-type cyclins accelerates $G_{1}$ phase in rodent fibroblasts. Genes Dev 7: 1559-1571.

Rajasekhar VK, Viale A, Socci ND, Wiedmann M, Hu X, Holland EC. 2003. Oncogenic Ras and Akt signaling contribute to glioblastoma formation by differential recruitment of existing mRNAs to polysomes. Mol Cell 12: 889-901.

Raught B, Gingras AC, Gygi SP, Imataka H, Morino S, Gradi A, Aebersold R, Sonenberg N. 2000. Serum-stimulated, rapamycin-sensitive phosphorylation sites in the eukaryotic translation initiation factor 4GI. EMBO J 19: 434-444.

Redpath NT, Foulstone EJ, Proud CG. 1996. Regulation of translation elongation factor-2 by insulin via a rapamycin-sensitive signalling pathway. EMBO J 15: 2291-2297.

Rojo F, Najera L, Lirola J, Jimenez J, Guzman M, Sabadell MD, Baselga J, Ramon y Cajal S. 2007. 4E-binding protein 1, a cell signaling hallmark in breast cancer that correlates with pathologic grade and prognosis. Clin Cancer Res 13: 81-89.

Rosenwald IB, Kaspar R, Rousseau D, Gehrke L, Leboulch P, Chen JJ, Schmidt EV, Sonenberg N, London IM. 1995. Eukaryotic translation initiation factor $4 \mathrm{E}$ regulates expression of cyclin D1 at transcriptional and post-transcriptional levels. J Biol Chem 270: 21176-21180.

Rousseau D, Kaspar R, Rosenwald I, Gehrke L, Sonenberg N. 1996. Translation initiation of ornithine decarboxylase and nucleocytoplasmic transport of cyclin D1 mRNA are increased in cells overexpressing eukaryotic initiation factor 4E. Proc Natl Acad Sci 93: 1065-1070.

Ruggero D, Montanaro L, Ma L, Xu W, Londei P, Cordon-Cardo C, Pandolfi PP. 2004. The translation factor eIF-4E promotes tumor formation and cooperates with c-Myc in lymphomagenesis. Nat Med 10: 484-486.

Ruvinsky I, Sharon N, Lerer T, Cohen H, Stolovich-Rain M, Nir T, Dor Y, Zisman P, Meyuhas O. 2005. Ribosomal protein S6 phosphorylation is a determinant of cell size and glucose homeostasis. Genes Dev 19: 2199-2211.

Sabatini DM. 2006. mTOR and cancer: Insights into a complex relationship. Nat Rev Cancer 6: 729-734. 
Sanchez-Cespedes M, Parrella P, Esteller M, Nomoto S, Trink B, Engles JM, Westra WH, Herman JG, Sidransky D. 2002. Inactivation of LKB1/STK11 is a common event in adenocarcinomas of the lung. Cancer Res 62: 3659-3662.

Sarbassov DD, Ali SM, Kim DH, Guertin DA, Latek RR, Erdjument-Bromage H, Tempst P, Sabatini DM. 2004. Rictor, a novel binding partner of mTOR, defines a rapamycin-insensitive and raptor-independent pathway that regulates the cytoskeleton. Curr Biol 14: 1296-1302.

Sarbassov DD, Guertin DA, Ali SM, Sabatini DM. 2005. Phosphorylation and regulation of Akt/PKB by the rictor-mTOR complex. Science 307: 1098-1101.

Scheper GC, Morrice NA, Kleijn M, Proud CG. 2001. The mitogen-activated protein kinase signal-integrating kinase Mnk2 is a eukaryotic initiation factor $4 \mathrm{E}$ kinase with high levels of basal activity in mammalian cells. Mol Cell Biol 21: $743-754$.

Schwanhausser B, Busse D, Li N, Dittmar G, Schuchhardt J, Wolf J, Chen W, Selbach M. 2011. Global quantification of mammalian gene expression control. Nature 473: 337-342.

Sengupta S, Peterson TR, Sabatini DM. 2010. Regulation of the mTOR complex 1 pathway by nutrients, growth factors, and stress. Mol Cell 40: 310-322.

Shahbazian D, Roux PP, Mieulet V, Cohen MS, Raught B, Taunton J, Hershey JW, Blenis J, Pende M, Sonenberg N. 2006. The mTOR/PI3K and MAPK pathways converge on eIF4B to control its phosphorylation and activity. $E M B O J \mathbf{2 5}$ : $2781-2791$.

Shaw RJ. 2009. LKB1 and AMP-activated protein kinase control of mTOR signalling and growth. Acta Physiol (Oxf) 196: $65-80$.

Shaw RJ, Cantley LC. 2006. Ras, PI(3)K and mTOR signalling controls tumour cell growth. Nature 441: 424-430.

Shaw RJ, Bardeesy N, Manning BD, Lopez L, Kosmatka M, DePinho RA, Cantley LC. 2004a. The LKB1 tumor suppressor negatively regulates mTOR signaling. Cancer Cell 6: 91-99.

Shaw RJ, Kosmatka M, Bardeesy N, Hurley RL, Witters LA, DePinho RA, Cantley LC. 2004b. The tumor suppressor LKB1 kinase directly activates AMP-activated kinase and regulates apoptosis in response to energy stress. Proc Natl Acad Sci 101: 3329-3335.

She QB, Halilovic E, Ye Q, Zhen W, Shirasawa S, Sasazuki T, Solit DB, Rosen N. 2010. 4E-BP1 is a key effector of the oncogenic activation of the AKT and ERK signaling pathways that integrates their function in tumors. Cancer Cell 18: 39-51.

Shima H, Pende M, Chen Y, Fumagalli S, Thomas G, Kozma SC. 1998. Disruption of the $\mathrm{p} 70^{\mathrm{s} 6 \mathrm{k}} / \mathrm{p} 85^{\mathrm{s} 6 \mathrm{k}}$ gene reveals a small mouse phenotype and a new functional S6 kinase. EMBO J 17: 6649-6659.

Shor B, Wu J, Shakey Q, Toral-Barza L, Shi C, Follettie M, Yu K. 2010. Requirement of the mTOR kinase for the regulation of Maf1 phosphorylation and control of RNA polymerase IIIdependent transcription in cancer cells. J Biol Chem 285: $15380-15392$.

Short MP, Richardson EP Jr, Haines JL, Kwiatkowski DJ. 1995. Clinical, neuropathological and genetic aspects of the tuberous sclerosis complex. Brain Pathol 5: 173-179.

Silvera D, Formenti SC, Schneider RJ. 2010. Translational control in cancer. Nat Rev Cancer 10: 254-266.

Sonenberg N, Hinnebusch AG. 2009. Regulation of translation initiation in eukaryotes: Mechanisms and biological targets. Cell 136: 731-745.

Spriggs KA, Bushell M, Willis AE. 2010. Translational regulation of gene expression during conditions of cell stress. Mol Cell 40: 228-237.

Stambolic V, Suzuki A, de la Pompa JL, Brothers GM, Mirtsos C, Sasaki T, Ruland J, Penninger JM, Siderovski DP, Mak TW. 1998. Negative regulation of PKB/Akt-dependent cell survival by the tumor suppressor PTEN. Cell 95: 29-39.

Stanners CP, Adams ME, Harkins JL, Pollard JW. 1979. Transformed cells have lost control of ribosome number through their growth cycle. J Cell Physiol 100: 127-138.
Suter M, Riek U, Tuerk R, Schlattner U, Wallimann T, Neumann D. 2006. Dissecting the role of $5^{\prime}$-AMP for allosteric stimulation, activation, and deactivation of AMP-activated protein kinase. J Biol Chem 281: 32207-32216.

Takagi M, Absalon MJ, McLure KG, Kastan MB. 2005. Regulation of $\mathrm{p} 53$ translation and induction after DNA damage by ribosomal protein L26 and nucleolin. Cell 123: 49-63.

Tang H, Hornstein E, Stolovich M, Levy G, Livingstone M, Templeton D, Avruch J, Meyuhas O. 2001. Amino acidinduced translation of TOP mRNAs is fully dependent on phosphatidylinositol 3-kinase-mediated signaling, is partially inhibited by rapamycin, and is independent of S6K1 and rpS6 phosphorylation. Mol Cell Biol 21: 8671-8683.

Thoreen CC, Kang SA, Chang JW, Liu Q, Zhang J, Gao Y, Reichling LJ, Sim T, Sabatini DM, Gray NS. 2009. An ATPcompetitive mammalian target of rapamycin inhibitor reveals rapamycin-resistant functions of mTORC1. J Biol Chem 284: 8023-8032.

Topisirovic I, Ruiz-Gutierrez M, Borden KL. 2004. Phosphorylation of the eukaryotic translation initiation factor eIF4E contributes to its transformation and mRNA transport activities. Cancer Res 64: 8639-8642.

Topisirovic I, Siddiqui N, Lapointe VL, Trost M, Thibault P, Bangeranye C, Pinol-Roma S, Borden KL. 2009a. Molecular dissection of the eukaryotic initiation factor 4E (eIF4E) export-competent RNP. EMBO J 28: 1087-1098.

Topisirovic I, Siddiqui N, Orolicki S, Skrabanek LA, Tremblay M, Hoang T, Borden KL. 2009b. Stability of eukaryotic translation initiation factor 4E mRNA is regulated by HuR, and this activity is dysregulated in cancer. Mol Cell Biol 29: $1152-$ 1162.

Topisirovic I, Svitkin YV, Sonenberg N, Shatkin AJ. 2011. Cap and cap-binding proteins in the control of gene expression. Wiley Interdisciplinary Reviews: RNA 2: 277298.

Tzur A, Kafri R, LeBleu VS, Lahav G, Kirschner MW. 2009. Cell growth and size homeostasis in proliferating animal cells. Science 325: 167-171.

Ueda T, Watanabe-Fukunaga R, Fukuyama H, Nagata S, Fukunaga R. 2004. Mnk2 and Mnk1 are essential for constitutive and inducible phosphorylation of eukaryotic initiation factor $4 \mathrm{E}$ but not for cell growth or development. Mol Cell Biol 24: 6539-6549.

Ueda T, Sasaki M, Elia AJ, Chio II, Hamada K, Fukunaga R, Mak TW. 2010. Combined deficiency for MAP kinase-interacting kinase 1 and 2 (Mnk1 and Mnk2) delays tumor development. Proc Natl Acad Sci 107: 13984-13990.

Walsh D, Mohr I. 2004. Phosphorylation of eIF4E by Mnk-1 enhances HSV-1 translation and replication in quiescent cells. Genes Dev 18: 660-672.

Wang W, Guan KL. 2009. AMP-activated protein kinase and cancer. Acta Physiol (Oxf) 196: 55-63.

Wang X, Flynn A, Waskiewicz AJ, Webb BL, Vries RG, Baines IA, Cooper JA, Proud CG. 1998. The phosphorylation of eukaryotic initiation factor eIF4E in response to phorbol esters, cell stresses, and cytokines is mediated by distinct MAP kinase pathways. J Biol Chem 273: 9373-9377.

Wang X, Yue P, Chan CB, Ye K, Ueda T, Watanabe-Fukunaga R, Fukunaga R, Fu H, Khuri FR, Sun SY. 2007. Inhibition of mammalian target of rapamycin induces phosphatidylinositol 3-kinase-dependent and Mnk-mediated eukaryotic translation initiation factor 4E phosphorylation. Mol Cell Biol 27: $7405-7413$.

Warburg O. 1956. On respiratory impairment in cancer cells. Science 124: 269-270.

Warner JR, McIntosh KB. 2009. How common are extraribosomal functions of ribosomal proteins? Mol Cell 34: 3-11.

Waskiewicz AJ, Flynn A, Proud CG, Cooper JA. 1997. Mitogen-activated protein kinases activate the serine/threonine kinases Mnk1 and Mnk2. EMBO J 16: 1909-1920.

Wendel HG, De Stanchina E, Fridman JS, Malina A, Ray S, Kogan S, Cordon-Cardo C, Pelletier J, Lowe SW. 2004. 
Survival signalling by Akt and eIF4E in oncogenesis and cancer therapy. Nature 428: 332-337.

Wendel HG, Silva RL, Malina A, Mills JR, Zhu H, Ueda T, Watanabe-Fukunaga R, Fukunaga R, Teruya-Feldstein J, Pelletier J, Lowe SW. 2007. Dissecting eIF4E action in tumorigenesis. Genes Dev 21: 3232-3237.

Woods A, Johnstone SR, Dickerson K, Leiper FC, Fryer LG, Neumann D, Schlattner U, Wallimann T, Carlson M, Carling D. 2003. LKB1 is the upstream kinase in the AMP-activated protein kinase cascade. Curr Biol 13: 2004-2008.

Wool IG. 1996. Extraribosomal functions of ribosomal proteins. Trends Biochem Sci 21: 164-165.

Worch J, Tickenbrock L, Schwable J, Steffen B, Cauvet T, Mlody B, Buerger H, Koeffler HP, Berdel WE, Serve H,
Muller-Tidow C. 2004. The serine-threonine kinase MNK1 is post-translationally stabilized by PML-RAR $\alpha$ and regulates differentiation of hematopoietic cells. Oncogene 23: 9162 9172.

Wullschleger S, Loewith R, Hall MN. 2006. TOR signaling in growth and metabolism. Cell 124: 471-484.

Zakikhani M, Dowling R, Fantus IG, Sonenberg N, Pollak M. 2006. Metformin is an AMP kinase-dependent growth inhibitor for breast cancer cells. Cancer Res 66: 10269-10273.

Zetterberg A, Larsson O, Wiman KG. 1995. What is the restriction point? Curr Opin Cell Biol 7: 835-842.

Zoncu R, Efeyan A, Sabatini DM. 2011. mTOR: From growth signal integration to cancer, diabetes and ageing. Nat Rev Mol Cell Biol 12: 21-35. 


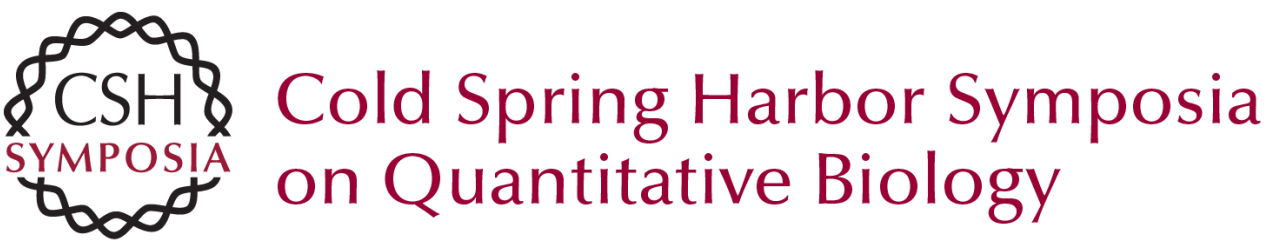

\section{mRNA Translation and Energy Metabolism in Cancer: The Role of the MAPK and mTORC1 Pathways}

I. Topisirovic and N. Sonenberg

Cold Spring Harb Symp Quant Biol 2011 76: 355-367 originally published online November 28, 2011

Access the most recent version at doi:10.1101/sqb.2011.76.010785

References This article cites 163 articles, 73 of which can be accessed free at: http://symposium.cshlp.org/content/76/355.full.html\#ref-list-1

\section{License}

Email Alerting Receive free email alerts when new articles cite this article - sign up in Service the box at the top right corner of the article or click here. 